\title{
Digestibility of Tanoak
}

\section{R. KIRBY AND D. A. BRYANT}

Highlight: Tanoak is considered a weed species in northwestern California. Dry-matter and cellulose digestibility trials were made with sheep to determine the possibility of using ground waste tanoak as an energy source in livestock rations. In vitro drymatter and cellulose digestibility values were consistently higher than the in vivo values. The in vitro dry-matter digestibility averaged $12.7 \%$ for four sheep, while the in vivo dry-matter digestibility averaged $8.9 \%$. The in vitro cellulose digestibility averaged $5.0 \%$; the in vivo cellulose digestibility averaged $1.0 \%$. It was concluded that tanoak residues can only have consideration as an energy source to ruminants when some form of pretreatment can release the wood carbohydrates from their association with lignin.

Tanoak (Lithocarpus densiflorus (Hook. and Arn.) Rehd.) (Fig. 1), considered to be a weed species, is the most abundant hardwood found in woodlands of northwestern California (Fowells 1965). It often grows in brush fields and reduces timber production and livestock grazing. Tanoak is also left lying on cut blocks as a logging residue.

Recycling of waste materials, like tanoak, as livestock feeds has become increasingly important. Wood industry by-products such as sawdust, chips, and logging slash show potential for conversion into inexpensive feeds that replace grain or supplements in livestock rations. Various studies have been conducted on the value of ground wood cellulose as an energy source in livestock rations. In vitro studies by Stranks (1959), Dinius and Baumgardt (1968), Millet et al. (1970), and Radwan and Crouch (1974), and an in vivo study by Mellenberger et al. (1971) show some untreated hardwoods to have relatively high digestibility values when used as energy feeds. Brush also appears to have potential as a source of energy for ruminants (Bissell and Weir 1957; Furbush et al. 1960; Furbush 1962; Hickman 1975).

The purpose of the following experiment was to determine the dry-matter and cellulose digestibility of tanoak, and to compare and evaluate two microtechniques used for the determination of wood digestibility.

\section{Materials and Methods}

Four rumen-fistulated Corriedale ewes, maintained on an all-alfalfa hay diet, provided inocula for in vitro trials and were the subjects of in vivo determinations.

Authors are researh technician, Department of Range Science, Texas A\&M University, College Station, Texas, and associate professor, Department of Range Management, Humboldt State University, Arcata, California, respectively. Kirby was formerly Technician I, Humboldt State Univ.

The research is approved by the Forest Service, Pacific Southwest Forest and Range Experiment Station, U.S. Department of Agriculture as cooperative agreement no. 21 352. It was partially supported financially by the Pacific Southwest Forest and Range Experiment Station.

The authors gratefully acknowledge the review of the manuscript by Drs. R. B. Sibley, R. B. Turner, and J. W. Stuth.

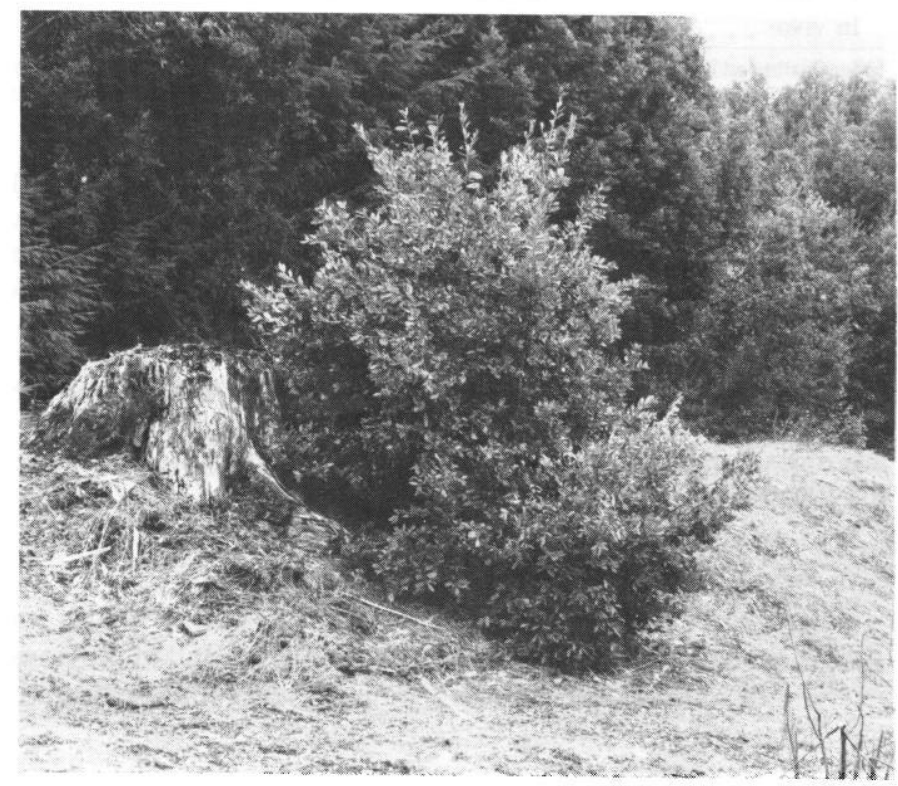

Fig. 1. A tanoak plant growing beside a Douglasfir stump on the study site.

The substrate for the digestibility trials was 50 whole tanoak plants. The plants were chipped in a portable chipper, ovendried at $60^{\circ} \mathrm{C}$ for 48 hours, and ground through a $0.5 \mathrm{~mm}$ screen in a Wiley mill. Ground samples were stored in sealed containers.

The in vitro analysis was patterned after that described by Mellenberger et al. (1970). Modifications included centrifuging the inocula at 250X gravity (Dehority et al. 1960), extending the incubation period to 72 hours, and releasing the internal pressure of the screwcap test tubes every 24 hours. After fermentation the tanoak residue was ovendried, and the dry-matter digestibility determined from the loss in weight. The residue was then analyzed for cellulose content. A correction factor for any dry matter added by the rumen ingesta was obtained by incubating a control tube of centrifuged ingesta and McDougall's buffer (McDougall 1949) for the same length of time as the samples.

The rumen-suspended, nylon bag technique of Van Keuren and Heinemann (1962) was used to investigate in vivo dry-matter digestibility. Modifications included attaching a stainless steel washer to the nylon bag, a 72-hour incubation period, and freezing the bag after digestion. After drying, the loss in weight was used to determine the dry-matter digestibility. The cellulose content of the tanoak residue was then determined.

Physical loss of sample through the bag was determined with beach sand, sifted to pass a 40-mesh screen. One gram of sand was placed in a nylon bag and suspended under running water for 24 hours. The loss in weight through the bag and in handling was found to be $0.007 \mathrm{~g}$ which was subtracted from dry-matter digestibility to give a corrected dry-matter digestibility. 
Table 1. Dry-matter and cellulose digestibility $(\%)$ of tanoak.

\begin{tabular}{lcl}
\hline $\begin{array}{c}\text { Variables } \\
\text { and categories }\end{array}$ & $\begin{array}{c}\text { Dry-matter } \\
\text { means }\end{array}$ & $\begin{array}{c}\text { Cellulose } \\
\text { means }\end{array}$ \\
\hline Time of trials & & \\
Period 1 & $13.2 \mathrm{a}^{1}$ & $2.0 \mathrm{a}$ \\
Period 2 & $10.2 \mathrm{~b}$ & $4.1 \mathrm{~b}$ \\
Period 3 & $10.0 \mathrm{~b}$ & $3.0 \mathrm{c}$ \\
Period 4 & $10.0 \mathrm{~b}$ & $3.0 \mathrm{c}$ \\
Sheep & & \\
1 & $10.6 \mathrm{a}$ & $2.5 \mathrm{a}$ \\
2 & $10.6 \mathrm{a}$ & $2.9 \mathrm{~b}$ \\
3 & $10.9 \mathrm{a}$ & $4.0 \mathrm{c}$ \\
4 & $11.4 \mathrm{a}$ & $2.7 \mathrm{ab}$ \\
Method & & \\
In vitro & $12.7 \mathrm{a}$ & $5.0 \mathrm{a}$ \\
In vivo & $8.9 \mathrm{~b}$ & $1.0 \mathrm{~b}$ \\
\hline
\end{tabular}

${ }^{1}$ Meas followed by the same letter are not significantly different $(0.05)$ as determined by Duncan's multiple range test. All comparisons are made within each column and variable.

The cellulose content of tanoak was analyzed before and after all digestibility trials by the method of Crampton and Maynard (1938). A modification by Hershberger et al. (1959) was used in the digestion step. Each cellulose analysis included one standard tanoak sample of a predetermined cellulose content.

A factorial analysis of variance was used to test for differences between replications, sheep, time of trial, procedure used, and the interactions between these factors. Differences between means of the two digestibility procedures were tested by Duncan's multiple range test (Steel and Torrie 1960).

\section{Results and Discussion}

The overall cellulose and dry-matter digestibility values for tanoak were higher than for many hardwoods tested in previous studies. In addition, the in vitro dry-matter and cellulose digesti-

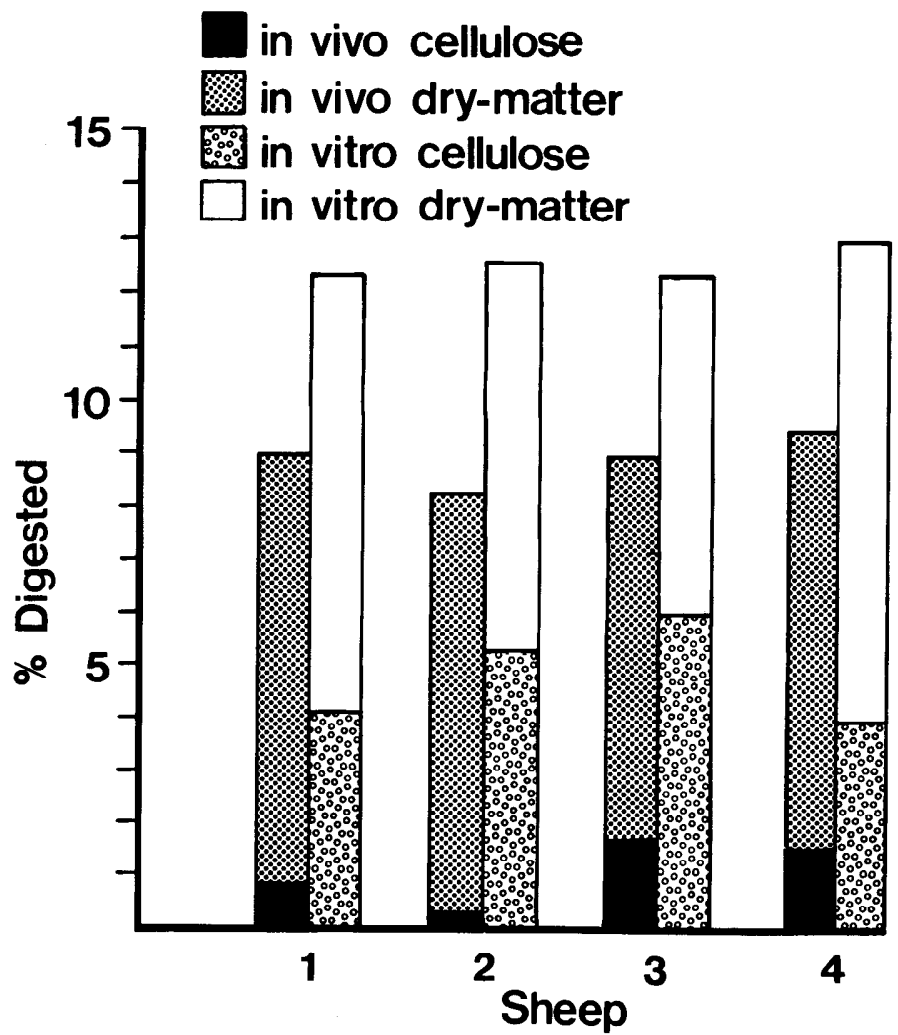

Fig. 2. In vitro and in vivo dry-matter and cellulose digestibility (\%) of tanoak among sheep. bilities were significantly higher than the in vivo values $(P \leq$ $.05)$.

\section{Dry-Matter Digestibility}

The method used and the time of trial were found to have significant differences at the 0.05 level of probability in the drymatter digestibility determination. There were no significant differences among sheep (Table 1).

The in vitro dry-matter digestibility averaged $12.7 \%$ and the in vivo averaged $8.9 \%$. In all replications, the in vitro drymatter digestibility values were equal to or greater than the in vivo values. Apparently the unique features of each method led to the differences in dry-matter digestibility.

The in vivo technique relied on nylon bags of a mesh size which presumably allowed microbes to pass into the bag. Possibly some small food particles were able to pass into the bag also. This would have added to the substrate, thereby lowering its apparent digestibility. Also, in the rumen, the microbes may have been preferentially selecting the alfalfa hay of the diet over the tanoak in the nylon bags. The in vitro technique of Mellenberger et al. (1970) optimized digestibility for woody plant species. In addition, the inocula used was subjected to straining and differential centrifugation, thus separating the microbes from the alfalfa particles of the diet. Therefore, both the in vivo and in vitro conditions probably contributed to the higher in vitro, lower in vivo digestibility values.

Sheep had no significant differences in their ability to digest tanoak. Mean dry-matter digestibility values ranged from $10.6 \%$ to $11.4 \%$. However, these figures are somewhat misleading. The in vitro dry-matter digestibility for each sheep ranged from $12.3 \%$ to $13.2 \%$ and the in vivo ranged from $8.4 \%$ to $9.7 \%$ (Fig. 2). The consistent results from each sheep indicate that the in vitro technique was the most efficient means of estimating the dry-matter digestibility of tanoak.

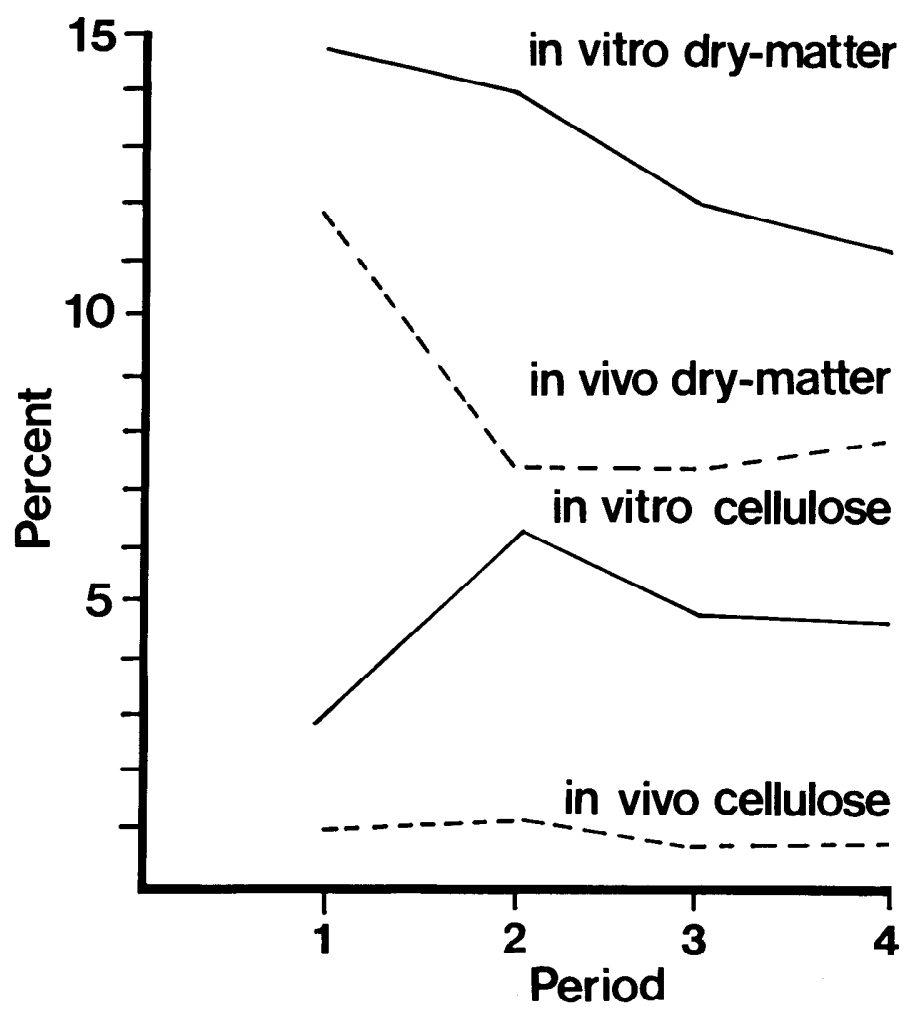

Fig. 3. Change in dry-matter and cellulose digestibility (\%) over time. 
Time had a significant influence on the dry-matter digestibility of tanoak. There was greater digestibility during the first period of the study than during subsequent periods (Table 1). After the first period the dry-matter digestibility leveled off for the remainder of the study. Both in vitro and in vivo results followed this pattern (Fig. 3). The marked difference between period one and following periods presumably was caused by stress from handling the sheep, not from any influence of tanoak. Changes in rumen environment such as aeration and repeated draining for ingesta collection may have caused fluctuations in the number and kind of anaerobic rumen microorganisms. In time, and with no increasing stress, a steady digestibility curve would likely occur (Fig. 3). Effects due to any influence of tanoak on rumen microorganisms would be expected to increase over time. which was not the case.

In vitro and in vivo dry-matter digestibility of tanoak was higher than some hardwoods of previous studies (Stranks 1959; Mellenberger et al. 1970; Millet et al. 1970; Mellenberger et al. 1971). In part this can be explained by the sampling procedures used. Leaf, bark, and bole material were included in the tanoak samples, whereas bole material was the primary sample source used in previous studies. Millet et al. (1970) found that bark, buds, and twigs of hardwoods yielded higher dry-matter digestibility values than bole material, since they contained less lignin and more digestible components.

\section{Cellulose Digestibility}

In vitro cellulose digestibility was significantly greater than that determined in vivo. Significant differences were also found among the sheep and times of the trials (Table 1).

No pattern or consistent results were found for time of trial or sheep. Cellulose digestion randomly differed among the sheep and times (Figs. 2 and 3). In all in vitro replications for each sheep and trail, cellulose digestion was greater than zero. This was not true for the in vivo cellulose digestibility results. At least one value of zero cellulose digestibility was found for three of the sheep and three of the four trials. Presumably preferential selection of substrates by the rumen microbes lowered overall in vivo cellulose digestibility values. In addition, small food particles including cellulose may have been able to infiltrate the nylon bag adding to cellulose content.

Values for digested cellulose were consistently lower than those for dry-matter digested for each technique. This agrees with the findings of Radwan and Crouch (1974) for red alder (Alnus rubra). Cellulose digested by the in vitro technique represented almost $40 \%$ of in vitro dry-matter loss. In vivo cellulose digested represented slightly over $10 \%$ of in vivo dry-matter digested.

These results strengthen the idea that the conditions of each technique were contributing to the differing digestibility values. The in vitro technique, with optimized artificial conditions, resulted in consistently greater digestibility. In contrast, the in vivo or "true" rumen digestion technique revealed lower digestibility values, probably due to microbial selection of an alternate feed source, the alfalfa ration.

\section{Conclusion}

As evident from these findings, tanoak residues can only have consideration as an energy source to ruminants when some form of pretreatment can release the wood carbohydrates from their association with lignin. Further research will be necessary to find commercially acceptable means of increasing tanoak's digestibility.

\section{Literature Cited}

Bissell, H. D., and W. C. Weir. 1957. The digestibility of interior live oak and chamise by deer and sheep. J. Anim. Sci. 16:476-480.

Crampton, E. W., and L. A. Maynard. 1938. The relation of cellulose and lignin content to the nutritive value of animal feeds. J. Nutrition 15:383-395.

Dehority, B. A., K. El-Shazly, and R. R. Johnson. 1960. Studies with the cellulolytic fraction of rumen bacteria obtained by differential centrifugation. J. Anim. Sci. 19:1098-1109.

Dinius, D. A., and B. R. Baumgardt. 1968. Ration dilution and feed intake in the sheep. J. Anim. Sci. 27:1767 (abstr.).

Fowells, H. A. 1965. Silvics of forest trees of the United States. U.S. Dep. Agr. Handbook No. 271.762 p.

Furbush, P. B., C. E. Carlson, and N. J. DalPorto. 1960. Cattle feeding trials using a pelleted brush roughage. Calif. Div. of Forest. Range Improvement Studies No. 4.13 p.

Furbush, P. B. 1962. Feed from brush. Calif. Div. of Forest., Sacramento. $24 \mathrm{p}$.

Hershberger, T. V., T. A. Long, E. W. Hartsook, and R. W. Swift. 1959. Use of the artificial rumen technique to estimate the nutritive value of forages. J. Anim. Sci. 18:770-779.

Hickman, O. E. 1975. Seasonal trends in the nutritive content of important range forage species near Silver Lake, Oregon. U.S. Dep. Agr. Forest Serv. Res. Paper PNW-187. 32 p.

McDougall, E. I. 1949. Studies on ruminant saliva. I. The composition and output of sheep's saliva. Biochem. J. 43:99-109.

Mellenberger, R. W., L. D. Satter, M. A. Millet, and A. J. Baker. 1970. $A n$ in vitro technique for estimating digestibility of treated and untreated woods. J. Anim. Sci. 30:1005-1011.

Mellenberger, R. W., L. D. Satter, M. A. Millet, and A. J. Baker. 1971. Digestion of aspen, alkali-treted aspen, and aspen bark by goats. J. Anim. Sci. 32:756-763.

Millet, M. A., A. J. Baker, W. C. Feist, R. W. Mellenberger, and L. D. Satter. 1970. Modifying wood to increase its in vitro digestibility. J. Anim. Sci. 31:781-788.

Radwan, M. A., and G. L. Crouch. 1974. Plant characteristics related to feeding preference by black-tailed deer. J. Wildl. Manage. 38:32-41.

Steel, G. D., and J. H. Torrie. 1960. Principles and procedures of statistics. McGraw-Hill Book Co., Inc., New York. 481 p.

Stranks, D. W. 1959. Fermenting wood substrates with a rumen cellulolytic bacterium. Forest Prod. J. 9:228-233.

Van Keuren, R. W., and W. W. Heinemann. 1962. Study of a nylon bag technique for in vivo estimation of forage digestibility. J. Anim. Sci. 21: 340-345.

After publication of our Research Note on a low-cost machine for the separation of rots from soil material (Journal of Range Management 29(6):506-507) we found we had inadvertently neglected to cite the following publication:

Van Wyk, J. J. P. 1974. A mechanical root washer. Proc. Grassld. Soc. South Afr. (9): 165-167.

Dr. Van Wyk developed the machine used by the IPB Grassland Biome.—J. Thilenius 